$\star$ Rhizomes: Cultural Studies in Emerging Knowledge: Issue 33 (2017)

\title{
Paula Byrne, The Genius of Jane Austen
}

\section{Megan Bruening Lehigh University}

Byrne, Paula. The Genius of Jane Austen: Her Love of Theatre and Why She Works in Hollywood. New York: Harper, 2017. \$16.99. 352pp.

It is not a profound statement to declare that Jane Austen is as popular as ever in the overlapping worlds of her devoted fans and her dedicated scholars. Yet the bicentennial of Austen's death has generated even more discussion including Paula Byrne's new work. The Genius of Jane Austen: Her Love of Theatre and Why She Works in Hollywood is a reworking (with a new chapter on film adaptations of Austen's work) of Byrne's 2013 book Jane Austen and the Theatre. The original book was favorably received and Byrne explains this republication is in direct response to the fervor surrounding the bicentennial.

The text is a fast-paced tour through the theatrical world eighteenth-century Britain: Byrne explains how this world influenced the beloved author's novels, and in turn the film adaptations of these novels. Her central thesis is that scholars have mistaken Austen's attitude towards the theatre as one of moral disapprobation, when in actuality theatre was "a formative influence on her comic art" (3). By arguing this point Byrne aspires to place Austen where she belongs, amongst the ranks of comic writers like William Shakespeare.

To contextualize her claim Byrne cites one critic (Lionel Trilling), but fails to explicitly acknowledge other scholars within the text with whom she engages. Her bibliography is lengthy (though in need of updating, as scholars such as Emily Anderson and Anne Widmayer have more recently considered how Austen's novels and the theatre intersect), but she rarely references other critics within the text itself. This lack of explicit conversation may be explained by positioning the book as designated for a public audience rather than a scholarly one.

Part 1 provides an overview of eighteenth-century theatre life and Austen's perceptive engagement with theatrical forms. Delving extensively into archival sources, Byrne firmly establishes that Austen loved the theatre, participating in private theatricals. As a child Austen watched her family perform plays, and she and Cassandra also acted in school productions. She did not act in 'adult' theatricals until her 30s, and by then she was well versed in the practices, trends, and actors of public theatre. Through her letters we see Austen's favorite actors' triumphs, and enjoy her scathing critiques of lesser performers. Tying all of these historical details together is Byrne's argument that Austen's interest in the theatre demonstrates a larger discursive interest in viewing social life through "the spectacles of theatre" (70). The first three chapters could act as a solid introduction for students interested in eighteenth-century theatre, a field often neglected. At times the amount of detail can be overwhelming (especially for a public audience), and some of Byrne's connections between contemporary theatre and Austen's novel choices seem tenuous: for example she links a one-line mention of the Astley's theatre in Emma to a debate over theatre patents (42).

Part 2 devotes a chapter to each novel (excluding Northanger Abbey and Persuasion), including two chapters on her early juvenilia and the play "Lover's Vows" that is so infamously performed in Mansfield Park. Byrne argues the early juvenilia is where the theatre's influence is most clearly seen: "Love and Freindship" for instance marks Austen's preference for burlesque comedy, and further indicates her preference for using comedy to resist sentimentalism (which Byrne claims is a theatrical as well as novel mode) (87). In the second chapter on the juvenilia Byrne focuses on Austen's theatrical adaptation of "Sir Charles Grandison," citing Richardson as a pioneer of dramatic novel writing to whom Austen would return as an adult (104). Moving into the major works, Byrne traces the influence of the theatre in each novel, focusing particularly on the use of indirect free speech and what 
she calls "set-pieces," or "chapters or episodes...[that] are often analogous in shape and length to a scene in a play" (5). When focused on these two concepts Byrne's analysis is insightful, but the chapters regularly give way to summaries (which makes us question again who the audience of this book is, as both scholars and experienced Austen fans would be bored by such repetition). She also frequently launches into comparisons between Austen's works and earlier novels, and while this strategy is clearly an attempt to rank Austen with more canonically recognized playwrights, this comparison sometimes makes Austen sound unoriginal. As a scholar of woman writers I was also disappointed at the imbalance of attention paid to female versus male writers. Although she does mention Inchbald and Cowley, they are not analyzed at the length that Sheridan, Fielding, and Richardson are. In doing so Byrne implicitly reinforces the male-centric canon that scholars have taken so much time (and still take so much time) to dismantle.

The final and new chapter explores film adaptations of Austen's novels, providing short summaries and explanations as to why each is or is not a successful adaptation. In Byrne's view, a successful adaptation maintains Austen's "comic spirit" (a vague term) and stands on its own as an entertaining piece of storytelling (262). According to this argument, "Clueless" and "Metropolitan" are two of the most successful film adaptations of Austen's novels (Emma and Mansfield Park respectively). Filled with interesting yet rushed points, this chapter could (and should) be an entire book on its own: it would be especially intriguing to consider, at greater length, how the strategies of indirect speech and set-pieces are translated into modern film techniques.

The Genius of Jane Austen is a solid entry point for fans of Austen that want to learn more about the entertainment world their beloved author experienced, and to look at the novels in a new context (or through the "spectacles of theatre"). Scholars and graduate students would appreciate Byrne's cross-form structure, though they might take issue with the lack of explicit scholarly engagement, and with some of the more repetitious summaries. Undergraduate students, on the other hand, might appreciate such summaries and teachers of undergraduate courses could use this text as a supplement to the novels in a Jane Austen or eighteenth-century British literature course. Byrne's work represents an emerging sphere of novel and theatre studies that will only continue to grow, and as such is to be commended for helping open the door of this new field.

\section{Cite this Review}

https://doi.org/10.20415/rhiz/033.r02

RHIZOMES ISSN 1555-9998 $\star 230$ East Hall Bowling Green State University Bowling Green, OH 43403

Editors: Ellen Berry and Carol Siegel. Reviews editor: Craig J. Saper. Technical editor: Helen J Burgess 